\title{
Challenging Body Condition Score in Monitoring Dairy Cow Physiology and Health
}

\section{Akbar Nikkhah}

Chief Highly Distinguished Professor, Department of Animal Sciences, Faculty of Agricultural Sciences, University of Zanjan, National Elite Foundation, Iran.

\begin{abstract}
Body condition scoring system (BSC), despite being a standardized management tool and global indicator of dairy cow peripheral adiposity, suffers from not monitoring visceral adiposity. The abdominal splanchnic fats are of increasing significance in management of metabolic disorders and farm economics. Efforts must be made to address such a major pragmatic shortcoming of BCS and seek insights to account for it in modern dairy farm management.
\end{abstract}

Keywords: Body Condition Score; Visceral Fat; Dairy Cow; Physiology; Health.

\section{*Corresponding Author:}

Akbar Nikkhah,

Chief Highly Distinguished Professor, Department of Animal Sciences, Faculty of Agricultural Sciences, University of Zanjan, National Elite Foundation, Iran.

Tel: +98-24-33052801

Fax: +98-24-33053202

E-mail: anikkha@yahoo.com nikkhah@znu.ac.ir

Recieved: March 05, 2015

Published: March 24, 2015

Citation: Akbar Nikkhah (2015) Challenging Body Condition Score in Monitoring Dairy Cow Physiology and Health. Int J Dairy Process Res. 2(2), 12-13. doi: http://dx.doi.org/10.19070/2379-1578-150004

Copyright: Akbar Nikkhah ${ }^{\circ}$ 2015. This is an open-access article distributed under the terms of the Creative Commons Attribution License, which permits unrestricted use, distribution and reproduction in any medium, provided the original author and source are credited.

\section{Introduction}

The current approach does rank cows mainly based on visual monitoring of fat (and indirectly muscle) tissues in relation to skeletal features of different areas of the cow body. The regions include cow back, hips, shoulders, hindquarters, tail-head, brisket, ribs, vulva and external rectum. This involves a 5 -scale scoring with 1 describing an extremely emaciated cow and 5 representing a very obese cow $[1,2]$. However, BCS provides no data on invisible central fats deposited abdominally within and around splanchnic tissues. The objective of this perspective article was to critically evaluate the current in-use body condition scoring system (BCS) in managing dairy cows.

\section{Discoveries and Discussion}

Such visceral adipose tissues are now increasingly known to sig- nificantly regulate visceral and peripheral biochemistry and whole dairy cow metabolism and health [3, 4]. Visceral fats include several adipose depots namely mesenteric, epididymal white adipose tissue, and perirenal fats. Visceral fats secret special proteins and messengers that when released into the liver, could highly induce inflammatory responses. These fats also produce hormones and proteins (e.g., leptin, resistin, adiponectin, and cytokines) that contribute to controlling feed intake and managing or exacerbating stress in transition and high-producing dairy cows. Visceral or abdominal adiposity may be closely linked to metabolic disorders and cardiovascular abnormalities as well as type 2 diabetes in human $[5,6]$. Moreover, in women, visceral fats are somehow associated with breast cancer and gallbladder complexities. Visceral fat is metabolically considered as an adipose tissue for being highly related to human and animal health status. However, subcutaneous fats or peripheral adipose tissues are not very much as such [5-8].

The conventional BCS system does in no way monitor visceral fat depots. As a result, it cannot estimate visceral fats contribution to dairy cow's energetics, metabolic stresses, altered physiology, and ultimate health. Being cognizant of such a major limitation is of crucial importance when different cows having similar BCS, may possess totally different amount of visceral fats and intermediary metabolism [3, 4]. Although, subcutaneous depots may quantitatively be correlated with visceral adiposity, the nature of such a relationship has not yet been substantively delineated towards possible accurate estimations. Few recent studies suggest that such relationships may exist but BCS suffers from a lack of precision in reliably estimating the amount of visceral fats and addressing their contributions to overall dairy cow metabolism and health $[3,4]$.

\section{Implications}

Despite offering a globally feasible and multi-benefit management tool, due to its incapability to accurately and precisely estimate the amount and type of visceral fat depots in dairy cows, BCS cannot 
monitor visceral fats contributions to altered cow physiology and health. This is of increasing importance in modern farming management since visceral adiposity is increasingly known to be highly related to risks form costly metabolic disorders such as fatty liver, systemic inflammation, ketosis, laminitis, mastitis, and metritis. Future research is required to describe on-farm approaches to overcome BCS limitations to optimize its application in managing dry, periparturient, and high-producing dairy cows.

\section{Acknowledgment}

Gratefully thanked are the Ministry of Science Research and Technology, National Elite Foundation, and University of Zanjan, Iran, for supporting the author's global programs of optimizing science edification in the third millennium.

\section{References}

[1]. Edmonson, A. J., Lean, I. J., Weaver, L. D., Farver, T., \& Webster, G. (1989). A body condition scoring chart for Holstein dairy cows. Journal of dairy science, 72(1): 68-78.

[2]. Wildman, E. E., Jones, G. M., Wagner, P. E., Boman, R. L., Troutt, H. F., $\&$ Lesch, T. N. (1982). A dairy cow body condition scoring system and its relationship to selected production characteristics. Journal of Dairy Science, 65(3): 495-501.

[3]. Nikkhah A. (2012). Visual Body Condition Score and Peripheral Metabolites and Insulin Responses to High and Low Dietary Energy Density in a Non-Pregnant Dry Cow Model. In Advances in Zoology Research. Volume 4. Editor: Owen P. Jenkins. Nova Science Publishers, New York, USA.

[4]. Nikkhah A. (2012). Visceral Adiposity and Splanchnic Organ Mass in NonPregnant Dry Holstein Cows Offered Higher and Lower Energy Diets. In Advances in Zoology Research. Volume 4. Editor: Owen P. Jenkins. New York, USA.

[5]. Montague CT, O'Rahilly S. (2000). The perils of portliness: Causes and consequences of visceral adiposity. Diabetes. 49 (6): 883-8.

[6]. Kern PA, Ranganathan S, Li C, Wood L, Ranganathan G. (2001). Adipose tissue tumor necrosis factor and interleukin-6 expression in human obesity and insulin resistance. Am. J. Physiol. Endocrinol. Metab. 280 (5): E745-51.

[7]. Marette A. (2003). Molecular mechanisms of inflammation in obesitylinked insulin resistance. Int. J. Obes. Metab. Disord. J. Int. Assoc. Stud. Obes. 27 Suppl 3: S46-8.

[8]. Mokdad AH, Ford ES, Bowman BA, Dietz WH, Vinicor F, Bales VS et al. (2003). Prevalence of obesity, diabetes, and obesity-related health risk factors, 2001. JAMA: the Journal of the American Medical Association. 289 (1): 76-9. 